\author{
Д'яконова А.К. \\ доктор технічних наук, професор \\ кафедра готельно-ресторанного бізнесу \\ E-mail: angela1943@ukr.net \\ ORCID ID: 0000-0001-6895-0780 \\ Тітомир Л.А. \\ кандидат технічних наук, доцент \\ кафедра готельно-ресторанного бізнесу \\ E-mail: mila_titomir@ukr.net \\ ORCID ID: 0000-0001-8676-4674
}

\author{
Трішин Ф.А. \\ кандидат технічних наук, доцент \\ кафредра автоматизації технологічних процесів \\ і робототехнічних систем \\ E-mail: fatrishyn@gmail.com \\ ORCID ID: 0000-0001-5994-3538 \\ Коротич О.M. \\ асистент \\ кафедра готельно-ресторанного бізнесу \\ Одеська національна академія харчових технологій \\ вул. Канатна, 112, м. Одеса, Україна, 65039 \\ E-mail: kelena1811@gmail.com \\ ORCID ID: 0000-0002-2680-976X
}

\title{
ІННОВАЦІЙНІ НАПРЯМКИ РОЗВИТКУ ЗАКЛАДІВ ГОТЕЛЬНОГО ГОСПОДАРСТВА
}

Готельний бізнес $є$ найперспективнішим сектором економіки, який успішно розвивається в Україні. Розширюються культурні і ділові зв'язки з країнами світу, що вимагає розміщення гостей в готелях нашої країни Швидкий ріст індустрії гостинності і збільшення попиту на готельні послуги свідчить про необхідність забезпечення якості готельних послуг. Ринок готельних послуг вимагає ефективних змін у відповідності з світовими інноваційними і інформаційними досягненнями. Реінжиніринг є інструментом, використання якого відкриває нові можливості для побудови ефективного виробництва з надання послуг, побудованого на нових принципах управління і спрямованого на підвищення якості обслуговування та задоволення гостей, які користуються послугами готельного підприємства. Для моделювання бізнес-процесів була використана методологія IDEF0, яка заснована на побудові функціональної деревовидної моделі діяльності готельного підприємства. Бізнес-процес розглядається як послідовність дій, спрямованих на досягнення кінцевого конкретного результату, який можна виміряти і оцінити. Ефективне управління змінами відноситься до найважливіших факторів успішної дії підприємств на міжнародному ринку. Реінжиніринг слід розглядати як комплексний метод управління змінами, який передбачає перебудову або перепроектування бізнес-процесів з урахуванням аналізу різних показників діяльності підприємства - організаційних, інформаційних, екологічних та інженерних.

Ключові слова: гостинність, конкурентоспроможність, послуга, якість обслуговування, реінжиніринг.

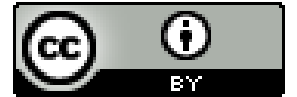

This work is licensed under a Creative Commons Attribution 4.0 International License http://creativecommons.org/licenses/by/4.0/
Постановка проблеми та її зв'язок з важливими науковими та практичними завданнями. Загострення конкуренції на світовому і внутрішньому ринку товарів та послуг дало поштовх розвитку і активному впровадженню інноваційних та інформаційних технологій в різних галузях виробництва у боротьбі за ринки збуту. Ведучу роль в ній стали відігравати галузі, які здатні безпосередньо задовольняти потреби людей. Аналіз бізнес-середовища і його змін, дослідження і аналіз потреб споживачів, є визначальними і стратегічно важливими для діяльності у сфері гостинності. Швидкі непередбачені зміни ринкового попиту потребують впровадження сучасних досягнень науки і техніки, заснованих на прогресивних технологіях, які дають змогу протистояти жорсткій конкурентній боротьбі за споживача, задоволення його вимог і сподівань.

На сьогодні будь-яке підприємство розгляда- ється як система, що базується на реалізації взаємопов'язаних процесів, які в сукупності визначають стан і конкурентоспроможність всієї організаційної системи. Ефективність роботи будь-якого підприємства значною мірою визначається процесами управління, їх відповідністю вимогам ринку товарів і послуг, які постійно змінюються. Прикладом є розвиток готельного бізнесу, ефективність якого значною мірою визначається організаційною структурою підприємства, впровадженням сучасних інноваційних i інформаційних технологій, орієнтацією на задоволення поточних і майбутніх потреб гостя. За даними Єврокомісії, протягом найближчих років, одним із основних факторів підвищення конкурентоспроможності підприємств на світовому ринку будуть інновації, які пов'язані з процесами управління [1].

Реінжиніринг бізнес-процесів - це науковопрактична діяльність, яка спрямована на повне 
переосмислення або перепроектування підприємства в цілому, або окремих бізнес-процесів, таких як взаємодія зі споживачами чи постачальниками. Згідно 3 класифікацією реінжинірингу бізнес-процесів, за видом діяльності, реінжиніринг поділяється на кризовий, коли необхідне повне перепроектування підприємства, і реінжиніринг розвитку, який базується на вдосконаленні певних бізнес-процесів для досягнення значного зростання основних показників діяльності підприємств гостинності, таких, як продуктивність праці, якість послуг, оперативність, скорочення витрат, збільшення прибутку.

В якості інноваційного підходу до реорганізації процесу управління на Заході широко впроваджують процесний підхід, який представляє собою сучасний науково-практичний напрямок використання інформаційних технологій у сфері виробництва та управління, і дозволяє провести реінжиніринг, тобто радикальне перепроектування бізнес-процесів, для досягнення корінного покращення показників діяльності підприємства, до складу яких входить комплекс організаційних, кадрових, комунікаційних, інформаційних і фінансових перетворень. Процесний підхід відкриває можливості створення ефективного виробництва $з$ надання готельних послуг, використовуючи принципи реінжинірингу, тому що він побудований на нових принципах управління і спрямований на постійне покращення якості продукції і задоволення гостей, які користуються послугами закладів гостинності.

Аналіз основних публікацій по проблемі. Готельний бізнес на сучасному етапі розвитку є складною системою економічних відносин, які включають різний набір послуг, що надаються гостям. Найбільш важливими 3 них $є$ розміщення, харчування, побутові, медичні та спортивно-оздоровчі послуги, зв'язок, розваги тощо.

В умовах постійної конкурентної боротьби у сфері гостинності, готельний бізнес потребує розробки і постійного вдосконалення стратегії розвитку підприємства відповідно до вимог ринку. Необхідна швидка адаптація до постійних змін зовнішнього середовища, а також розробка стратегії інноваційного розвитку підприємства. Тому питанням управління готельного бізнесу були присвячені роботи А. Л. Лісника і А. В. Чернишової [2], Н. І. Кабушкіна [3], М. В. Сфремової [4], Е. О. Джанджугазової [5], М. П. Мальської, і І.Г. Пандяка [6], О. І. Громова [7] та ін., В.В. Репін особливу увагу приділив процесному підходу до управління і моделювання бізнес-процесів [8].

Життєздатність готельного бізнесу пов'язана 3 його можливістю прилаштуватися до потреб зовнішнього і внутрішнього середовища. Для забезпечення конкурентоспроможності підприємства гостинності почали орієнтуватися на якість продукції і наданих послуг. У зв'язку з цим значно зросла потреба у висококваліфікованих кадрах, які здатні впроваджувати новітні інформаційні технології, а також відповідати вимогам нової організаційної культури.

В умовах жорсткої конкуренції і постійно зростаючих вимог споживачів до якості послуг та їх оперативного виконання, не можливо задовільнити потреби споживачів без впровадження реінжинірингу, який базується на використанні інноваційних технологій та інформаційних систем управління.

Формування цілей дослідження. Мета статті полягає у теоретичному обгрунтуванні процесу впровадження принципів реінжинірингу на підприємствах готельного бізнесу з використанням процесного моделювання, для підвищення ефективності управлінських рішень, і формування системи показників, що визначають ефективність впровадження реінжинірингу.

Виклад основних результатів та їх обгрунтування. На сьогодні виникла необхідність у зміні самого процесу управління на принципах реінжинірингу, тому що функціональний підхід до управління, який широко використовувався в Україні, не відповідає новим економічним умовам сьогодення.

Безперервні зміни в технологіях, ринках збуту і потребах клієнтів стали звичайним явищем, i компанії, які прагнуть зберегти свою конкурентоспроможність, змушені безперервно перебудовувати i удосконалювати корпоративну стратегію діяльності закладу.

Існує цілий ряд бізнес-процесів, які потребують використання реінжинірингу, а саме: диверсифікація товарів і послуг, які орієнтовані на різні сегменти ринку, що потребує різних бізнес-процесів; впровадження інноваційних технологій, які пов'язані 3 основними бізнес-процесами підприємства; різноманітність зв'язків з партнерами підприємства, постачальниками сировини і матеріалів; нераціональність організаційної структури, що призводить до дублювання операцій бізнес-процесу; виконання індивідуальних заказів, що вимагає адаптації бізнес-процесу до особистих вимог клієнта тощо.

Реінжиніринг - це складний процес, який базується на певних принципах, використання яких дозволяє прискорити виконання робіт, скоротити витрати часу i ресурсів. Він заснований на наступних принципах: кілька робочих процедур поєднуються в одну; робота виконується у природній послідовності; виконавці процесу самостійно приймають рішення; робота виконується там, де це доцільніше; процеси мають різні варіанти виконання; мінімізація кількості узгоджень; зменшення кількості входів у процеси; зниження кількості перевірок та контролю; поєднання централізованих i децентралізованих операцій; використання загальної інформаційної мережі операційними менеджерами [9]. Наведені принципи вказують чіткий напрямок реалізації бізнес-процесів.

Впровадження принципів реінжинірингу сприяє зниженню дії бюрократичного механізму, забезпеченню ефективності дії системи мотивації роботи персоналу і взаємної відповідальності за результат бізнес-процесу між всіма його учасниками. Інструментом цих перетворень $€$ реінжиніринг бізнеспроцесів, який змінює відношення людей до праці, корегує бізнес-процеси і технології виробництва. Тобто процесний підхід відкриває нові можливості 
для побудови ефективного виробництва на принципах реінжинірингу. В результаті впровадження принципів реінжинірингу відбувається: відмова від застарілих методів управління; орієнтація на досягнення результату, а не на виконання завдання; творчий підхід до виконання роботи; спрощення або видалення зайвих елементів в процесі; застосовування інноваційних та інформаційних технологій, що забезпечують підвищення ефективності бізнес-процесів 3 надання послуг в закладах гостинності.

У зв'язку з цим необхідно мати чітко визначені стратегічні плани роботи організації, окреслити бізнес-процеси, які відбуваються на підприємстві i суттєво впливають на якість продукції або послуг, визначитись 3 ресурсами підприємства, розуміти взаємозв'язки між процесами діяльності підприємства, оцінити роль різноманітних факторів, що впливають на готельний бізнес.

Структура управління кожного готелю представляє собою складну динамічну систему, яка змінюється у часі в залежності від обставин і вимог ринку збуту, а саме споживачів готельних послуг. Це складне завдання дозволяє вирішити побудова моделі бізнес-процесів, які наочно дають змогу побачити доцільність проведення реорганізації системи управління i технологічних бізнес-процесів, визначити шляхи впровадження принципів реінжинірингу.

В першу чергу необхідно побудувати модель бізнесу, яка показує, яким чином здійснюється взаємодія всіх бізнес-процесів на підприємстві. Модель бізнесу показує працівникам усіх рівнів, що має бути зроблено для надання якісних готельних послуг, в які терміни і яким саме чином. Вона об'єднує різні потоки подій, пов'язаних з обслуговуванням гостей готельних закладів. Тому необхідно розробляти комплекс бізнес-моделей, які повинні бути інтегровані і узгоджені між собою.
Для кожної категорії співробітників готельного господарства необхідна інформація, що стосується їх виду діяльності. Бізнес-моделі дозволяють визначити ризики, уникнути помилок і підвищити ймовірність успіху при управлінні організацією. Це особливо важливо для сфери послуг, тому що цей сектор сучасної економіки швидко розвивається і забезпечує від 60 до 70 \% національного продукту [10].

Крім того, послуги, які надаються в сфері гостинності, не можна зберігати, що визначає основні завдання реінжинірингу, тобто підвищення продуктивності праці і управління людськими ресурсами. Тому, саме реінжиніринг бізнес-процесів на основі інформаційних технологій здатен найбільш ефективно вирішити проблему підвищення продуктивності праці без зниження якості обслуговування.

Реінжиніринг як метод управління діяльністю підприємства, складається 3 двох взаємопов'язаних методів: зворотного і прямого інжинірингу. Зворотний реінжиніринг $є$ методом підготовки бази даних для проектування нової конкурентної стратегії, прямий реінжиніринг являє собою методологію формування і реалізації новостворюваної концепції підприємства. У процесі зворотного інжинірингу проводиться комплексний аналіз підприємства, який включає діагностику існуючих бізнес-процесів, і здійснюється проектування нової моделі діяльності підприємства. На основі результатів аналізу масиву даних, отриманих при проведені зворотного інжинірингу, створюється принципово нова модель конкурентоспроможної бізнес структури, формуються нові бізнеспроцеси діяльності підприємства на основі принципів реінжинірингу бізнес-процесів. Впровадження реінжинірингу бізнес-процесів на діючому підприємстві складається з кількох етапів (табл. 1).

Таблиця 1

Етапи проведення реінжинірингу бізнес-процесів *

\begin{tabular}{|c|c|}
\hline Назва етапу & Характеристика процесів по етапах \\
\hline $\begin{array}{l}\text { 1. Розробка перспективної моделі } \\
\text { функціонування підприємства }\end{array}$ & $\begin{array}{l}\text { На цьому етапі формується бажана модель підприємства «як повинно } \\
\text { бути», яка включає опис функцій, учасників, ресурсів, інформаційні } \\
\text { потоки, послідовність дій, чіткий розподіл прав і обов’язків праців- } \\
\text { ників, методи контролю }\end{array}$ \\
\hline $\begin{array}{l}\text { 2. Аналіз діючих бізнес-процесів } \\
\text { управління на підприємстві }\end{array}$ & $\begin{array}{l}\text { На цьому етапі проводиться аналіз діючих на підприємстві бізнес- } \\
\text { процесів для виявлення проблемних зон, будується модель бізнес- } \\
\text { процесу «як є» для оцінки реального стану справ, документація та } \\
\text { інформаційних потоків }\end{array}$ \\
\hline $\begin{array}{l}\text { 3. Перепроектування підприємства } \\
\text { на принципах реінжинірингу }\end{array}$ & $\begin{array}{l}\text { На цьому етапі проводиться порівняльний аналіз розроблених моде- } \\
\text { лей для визначення напрямку перепроектування, проблемних місць і } \\
\text { зав'язків, які необхідно корегувати, розробляються заходи, визнача- } \\
\text { ються методи, методики та інструменти, проводиться опробування } \\
\text { перепроектованої моделі бізнес-процесів }\end{array}$ \\
\hline $\begin{array}{l}\text { 4. Оптимізація перепроектованих } \\
\text { бізнес-процесів }\end{array}$ & $\begin{array}{l}\text { На цьому етапі проводиться виправлення виявлених помилок і недо- } \\
\text { ліків у розробленій за принципами реінжинірингу моделі бізнес- } \\
\text { процесів, оптимізація перебудованих і створених бізнес-процесів, } \\
\text { аналіз впливу змін структури управління і бізнес-потоків на ефектив- } \\
\text { ність роботи підприємства }\end{array}$ \\
\hline
\end{tabular}

*Розроблено авторами на основі джерел $[11,12]$ 
Проведення реінжинірингу бізнес-процесів на діючих підприємствах гостинності $\epsilon$ складною процедурою, у зв'язку з тим, що охоплює велику кількість різноманітних, взаємопов'язаних бізнеспроцесів. Тому для проведення реінжинірингу бізнеспроцесів, необхідно залучати спеціалістів, які мають певний досвід у побудові комплексу нових бізнесмоделей, впровадження яких забезпечить реорганізацію управлінської структури і технологічних бізнеспроцесів виробництва.

Всі заходи з реінжинірингу бізнес-процесів повинні відповідати стратегічному напрямку дії підприємства, а кожний етап впровадження реінжинірингу виробництва необхідно оформлювати документально, що дозволить реально оцінити ефективність впроваджених заходів і вивести підприємство на наступний етап розвитку.

На кожному етапі виробничих бізнеспроцесів в готельному бізнесі використовуються різні показники оцінки ефективності діяльності підприємства, але до основних можна віднести наступні: скорочення витрат часу на управлінські рішення і інформаційно-ресурсне забезпечення; скорочення часу на підготовку i реалізацію бізнес-процесу та витрати матеріальних ресурсів; зменшення собівартості продукції або послуг; збільшення обсягів реалізації продукції або послуг; збільшення прибутку; розширення ринку збуту готельних послуг; підвищення продуктивності праці; скорочення часу простоїв у виробничому циклі; приріст рентабельності підприємства; поліпшення взаємодії вертикальних і горизонтальних зав'язків; задоволення гостей готелю і скорочення скарг; зменшення часу на укладання договорів; задоволення працівників організацією праці і можливістю професійного розвитку; чітке розподілення обов'язків та відповідальності; відмова від бюрократичних схем і перехід до командної співпраці. Підприємство стає більш адаптованим до змін, які постійно відбуваються у зовнішньому середовищі, відбувається перехід від застарілих схем управління до інноваційних методів і сучасних інформаційних систем, що підвищує його конкурентоспроможність.

Сфера гостинності, для підвищення ефективності наданням послуг, вимагає впровадження розвиненої інформаційної системи, а також застосування спеціальних методів, методик та інструментів. Тому останнім часом значно зріс інтерес до CASEтехнологій (Computer-Aided Software Engineering) та інструментальних CASE-засобів, що дозволяють максимально систематизувати та автоматизувати всі етапи програмного забезпечення проекту з впровадження принципів реінжинірингу [13].

Встановлено, що найкращою методологічною основою бізнес-процесів у сфері гостинності служить методологія структурного аналізу і проектування (SADT), або добре розроблене на ії базі сімейство методологій IDEF, що є державним стандартом в США [8]. Технологія моделювання IDEF гарантує внесення на розгляд тільки мінімально необхідного набору елементів технологічного процесу, кількість яких достатня для досягнення основних результатів діяльності модельованої системи.

IDEF0 - нотація графічного моделювання, яка використовується для створення функціональної моделі, відображає структуру і функції системи, а також потоки інформації і матеріальних об’єктів, які зв'язують ці функції.

Модель AS-IS - це модель «як є», тобто модель вже існуючого процесу. Аналіз процесів є обов'язковою частиною будь-якого проекту створення або розвитку системи. Побудова функціональної моделі AS-IS дозволяє чітко зафіксувати, які процеси здійснюються на підприємстві, які інформаційні об'єкти використовуються при виконанні функцій різного рівня деталізації.

Модель AS-IS показує зони відповідальності виконавців процесу і хід самого процесу, тобто «хто що зробив», як взаємопов'язані етапи між собою і як кожен етап впливає на кінцевий результат. Функціональна модель AS-IS є відправною точкою для аналізу роботи підприємства, виявлення проблем для розробки проекту вдосконалення ділових процесів. Аналіз функціональної моделі AS-IS дозволяє зрозуміти, в чому полягає проблема, в чому будуть полягати переваги нових процесів і яким змінам піддасться існуюча структура організації процесу в результаті оптимізації.

IDEF0 - це контекстна або верхня діаграма, на якій об'єкт моделювання представлений єдиним блоком з граничними стрілками. Ця діаграма називається А-0 (рис. 1).

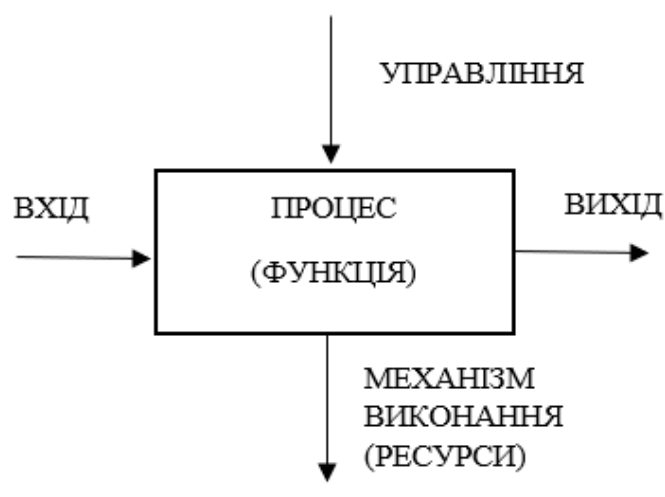

Рис 1. Контекстна діаграма процесу надання готельних послуг в нотації IDEF0 [14] 
Стрілки на цій діаграмі відображають зв'язки об'єкта моделювання 3 навколишнім середовищем споживачами, постачальниками, виконавцями тощо. Діаграма А-0 або контекстна діаграма встановлює область моделювання та іiі межі. Нотація IDEF0 деталізує послідовну декомпозицію процесу за допомогою деталізованих до необхідного рівня дочірніх діаграм.

Контекстна діаграма включає тільки один блок, який характеризує сукупність процесів, що моделюються.

Функція «вхід» включає наступні процеси: замовлення на бронювання номеру в готелі; зустріч гостя; реєстрація гостя; наявність вільних номерів відповідно до уподобань гостя; спосіб розрахунку гостя; інноваційні і інформаційні технології, що використовуються в готелі.

Функція «управління» охоплює наступні елементи: державні накази; стандарти; постанови і розпорядження керівництва закладу; методи виконання послуг; методи контролю наданих послуг.

Функція «механізм виконання» включає елементи: персонал готелю; обладнання та технічні засоби, що використовується для надання послуг; офісна техніка - телевізор, комп’ютер, телефон, Wi-Fi тощо.

Функція «вихід» охоплює наступні процеси: звільнення номеру; розрахунок за надані послуги; ступінь задоволення гостя; прибирання звільненого номеру.
Таким чином, функція бізнес-процесів готельних послуг дозволяє чітко визначити потреби гостя при заселенні, які функції, в якій послідовності і ким виконуються процеси надання послуг. Результатом виконання бізнес-процесів при використанні номерного фонду готелю є задоволений гість і фінансові надходження для закладу.

Висновки і перспективи подальших досліджень. Використання процесних методів дослідження на базі інноваційних i інформаційних методів управління у сфері готельного бізнесу є ефективним засобом вирішення проблеми вдосконалення і покращення готельних послуг у відповідності до вимог міжнародних стандартів, провести реінжиніринг i підвищити конкурентоздатність діючих закладів готельного господарства. Запропонований методичний підхід до формування оцінки показників з визначення ефективності проведеного реінжинірингу виробництва 3 використанням процесного проектування на всіх етапах виробництва, дозволяє визначити на скільки нова модель підприємства наближена до бажаної моделі функціонування підприємства.

В перспективі автори планують провести дослідження процесів постачання і забезпечення закладів готельного господарства, визначити рівень впровадження інноваційних і інформаційних технологій та якість послуг, які надаються в закладах гостинносTi.

\section{Література}

1. Управление бизнес-процессами современных организаций: монография / под общ. ред. М.М. Максимцова; МГСУ. М., 2009. 311 с.

2. Лісник А.Л., Чернишов А.Л. Організація управління готельним бізнесом: підручник. М.: Видавничий дім «Альпіна», 2015. 315 с.

3. Кабушкин, Н. І. Менеджмент гостиниц и ресторанов: учеб. пособие. Минск: КНОРУС, 2013. 416 с.

4. Ефремова М. В. Сегментация потребителей гостиничных услуг // Маркетинг в России и за рубежом. 2002. №. 2. С. 72-81.

5. Джанджугазова Е. А. Маркетинг в индустрии гостеприимства: учеб. пособие. М.: Академия, 2005. $224 \mathrm{c}$.

6. Мальська М. П., Пандяк І.Г. Готельний бізнес: теорія та практика: підручник. К.: Центр учбової літератури, 2010. $472 \mathrm{c}$.

7. Громов А.И., Фляйшман А., Шмидт В. Управление бизнес-процессами: современные методы: монография. М.: Издательство «Юрайт», 2019. 367 с.

8. Репин В. В., Елиферов В.Г. Процессный подход к управлению. Моделирование бизнес-процессов. М.: Манн, Иванов и Фербер, 2013. 544 с.

9. Гвоздь М.Я. Реінжиніринг бізнес-процесів як чинник прискореного розвитку економіки // Вісник Національного університету «Львівська політехніка». № 754: Проблеми економіки та управління. Львів, 2013. C. 135-138.

10. Медлик С., Инграм Х. Гостиничный бизнес: учеб. для студ. М.: Юнити-Дана, 2015. 239 с.

11. Бабак О.Я. Реінжиніринг як сучасний інструмент інноваційної діяльності підприємств // Економічний вісник Переяслав-Хмельницького ДПУ. 2011. № 17/1. С. 55-60.

12. Дикань В.Л., Слагін Ю.В., Корінь М.В. Реінжиніринг бізнес-процесів піжприємств: конспект лекцій. Харків: УкрДАЗТ, 2011. 62 с.

13. Bertolini M., Bevilacqua M., Ciarapica F.E. \& Giacchetta G. Business process re-engineering in healthcare management: a case study // Business Process Management Journal. 2011. Vol. 17. Iss. 1. P. 42-66. doi: $10.1108 / 14637151111105571$

14. Блинов А.О. Реинжиниринг бизнес-процессов: учеб.пособ. Москва: ЮНИТИ-ДАНА, 2010. 343 с.

Стаття надійшла 29.12.2020

Стаття прийнята до друку 15.01.2021

Доступно в мережі Internet 18.04.2021 
Dyakonova A.

Doctor of Technical Sciences, Professor

Department of Hotel and Restaurant Business

E-mail: angela1943@ukr.net

ORCID ID: 0000-0001-6895-0780

\section{Titomyr L.}

Ph.D., Associate Professor

Department of Hotel and Restaurant Business

E-mail: mila_titomir@ukr.net

ORCID ID: 0000-0001-8676-4674
Trishyn F.

Ph.D., Associate Professor

Department of Automation of Technological

Processes and Robotic Systems

E-mail: fatrishyn@gmail.com

ORCID ID: 0000-0001-5994-3538

Korotych 0.

Assistant

Department of Hotel and Restaurant Business

Odesa National Academy of Food Technologies

Kanatna str., 112, Odesa, Ukraine, 65039

E-mail: kelena1811@gmail.com

ORCID ID: 0000-0002-2680-976X

\section{INNOVATIVE DIRECTIONS FOR THE DEVELOPMENT OF HOTEL FACILITIES}

The hotel business is the most promising and profitable direction of the economy, which is successfully developing in Ukraine. Cultural and business relations with other countries of the world are expanding, which requires the accommodation of guests in hotels of our country. The rapid growth of tourism and the increase in demand for hotel services require improving their quality to the level of international standards. The market of hotel services requires effective changes in accordance with the world innovation and information achievements. The introduction of innovative technologies into the hotel business allows to reduce consumption of energy, labour, and raw material resources, to make efficient use of production space, to reduce the duration of reception, accommodation and service of hotel guests. The purpose of the article is to theoretically substantiate the implementation of the principles of reengineering in the hotel business using process modelling, and to form the systems of indicators that determine the efficiency of implemented managerial decisions. Reengineering is a tool, the use of which opens up new opportunities for building efficient production to provide services, built on new principles of management and aimed at improving the quality of service and satisfaction of guests who use the services of the hotel business. For business process modelling, the IDEF0 methodology was used, which is based on the construction of a functional tree-like model of the hotel business activity. A business process is considered as a sequence of actions aimed at achieving a final concrete result that can be measured and evaluated. The efficient change management is one of the most important factors for the successful operation of enterprises in the international market. Reengineering should be considered as a comprehensive method of change management, which involves the restructuring or redesigning of business processes, taking into account the analysis of various indicators of the enterprise activity - organizational, informational, environmental and engineering.

Key words: hospitality, competitiveness, service, quality of service, reengineering.

\section{References}

1. Maksimtsova, M. M. (Ed.). (2009). Upravlenie biznes-protsessami sovremennyih organizatsiy. Moscow: MGSU.

2. Lisnyk, A. L., \& Chernyshov, A. L. (2015). Orhanizatsiia upravlinnia hotelnym biznesom. Moscow: Vydavnychyi dim «Alpina».

3. Kabushkin, N. I. (2013). Menedzhment gostinits i restoranov. Minsk: KNORUS.

4. Efremova, M. V. (2002). Segmentatsiya potrebiteley gostinichnyih uslug. Marketing v Rossii i za rubezhom, (2), 72-81.

5. Dzhandzhugazova, E. A. (2005). Marketing v industrii gostepriimstva. Moscow: Akademiya.

6. Malska, M. P., \& Pandiak, I.H. (2010). Hotelnyi biznes: teoriia ta praktyka. Kyiv: Tsentr uchbovoi literatury.

7. Gromov, A. I., Flyayshman, A., \& Shmidt, V. (2019). Upravlenie biznes-protsessami: sovremennyie metodyi. Moscow: Izdatelstvo «Yurayt».

8. Repin, V. V., \& Eliferov, V.G. (2013). Protsessnyiy podhod k upravleniyu. Modelirovanie biznes-protsessov. Moscow: Mann, Ivanov i Ferber.

9. Hvozd, M. Ya. (2013). Reinzhynirynh biznes-protsesiv yak chynnyk pryskorenoho rozvytku ekonomiky. Visnyk Natsionalnoho universytetu «Lvivska politekhnika», (754). Problemy ekonomiky ta upravlinnia, 135-138.

10. Medlik, S., \& Ingram, H. (2015). Gostinichnyiy biznes. Moscow: Yuniti-Dana. 
11. Babak, O. Ya. (2011). Reinzhynirynh yak suchasnyi instrument innovatsiinoi diialnosti pidpryiemstv. Ekonomichnyi visnyk Pereiaslav-Khmelnytskoho DPU, (17/1), 55-60.

12. Dykan, V. L., Yelahin, Yu. V., \& Korin, M. V. (2011). Reinzhynirynh biznes-protsesiv pizhpryiemstv. Kharkiv: UkrDAZT.

13. Bertolini, M., Bevilacqua, M., Ciarapica, F. E., \& Giacchetta, G. (2011). Business process re-engineering in healthcare management: a case study. Business Process Management Journal, 17(1), 42-66. doi: $10.1108 / 14637151111105571$

14. Blinov, A. O. (2010). Reinzhiniring biznes-protsessov. Moscow: YuNITI-DANA.

Received 29 December 2020

Approved 15 January 2021

Available in Internet 18.04.2021

Цитування згідно ДСТУ 8302:2015

Д'яконова А.К., Трішин Ф.А., Тітомир Л.А., Коротич О.М. Інноваційні напрямки розвитку закладів готельного господарства // Економіка харчової промисловості. 2021. Т.13, вип. 1. С.62-68.

Cite as APA style citation

Dyakonova, A., Trishyn, F., Titomyr, L., \& Korotych, O. (2021). Innovative directions for the development of hotel facilities. Food Industry Economics, 13(1), 62-68. 